\title{
Hematological Profile of the Juvenile Carp (Cyprinus carpio, L. 1758) Reared into a Recirculating Aquaculture System with Probiotics Supplement
}

\author{
Elena BOCIOC*1), Victor CRISTEA ${ }^{1)}$, Neculai PATRICHE ${ }^{2)}$, Iulia GRECU ${ }^{1)}$, \\ Alina ANTACHE ${ }^{1)}$, Mirela (CREŢU) MOCANU ${ }^{1)}$ \\ ${ }^{1)}$ University "Dunarea de Jos" of Galați, Department of Aquaculture, Environmental Science \\ and Cadastre, 61-63 Gării Street, 800003 Galați, Romania; \\ ${ }^{2)}$ Institute for Research and Development in Aquatic Ecology, Fishing and Aquaculture, \\ 2-4 Portului Street, 800032 Galati, Romania. \\ *Corresponding author, email: elenabocioc@yahoo.com
}

Bulletin UASVM Animal Science and Biotechnologies 72(1) / 2015

Print ISSN 1843-5262; Electronic ISSN 1843-536X

DOI:10.15835/buasvmcn-asb:10739

\begin{abstract}
The use of probiotics in aquaculture is gained increasing scientific and commercial interest for promoting as growth supplements, mostly, but as prophylactic or therapeutic agents, too. The intensive fish rearing often are characterized by stressful conditions (overcrowd, altered water quality etc.) so, the probiotics could help by enhancing the resistance to stress. In teleostean fish, hematological indices are used as indicators of the physiological stress response to internal or external factors disturbances. Currently, there is limited information on the efficacy of the probiotics and its impact on fish blood physiology.

The general aim of this paper was to assess the effect of a probiotic supplements (BioPlus $® 2 B$ ) on hematological status in common carp (Cyprinus carpio, Linnaeus 1758), cultured in a recirculating aquaculture system and fed with a commercial diet with $30 \%$ raw protein.

The experiment was performed for 60 days, fish biomass being equally distributed into the 4 growth units (V1-control and three different concentrations of probiotics: $\mathrm{V} 2-2.24 \times 10^{9} \mathrm{CFU} / \mathrm{kg}$ food, $\mathrm{V} 3-3.84 \times 10^{9} \mathrm{CFU} / \mathrm{kg}$ food, $\mathrm{V} 4-7.04 \times 10^{9} \mathrm{CFU} / \mathrm{kg}$ food). Blood samples were drawn at both the beginning and the end of the trial period.

The researches revealed a great range of variability for the hematological parameter as follows: (Hb) hemoglobin $3.40 \div 11.00 \mathrm{~g} / \mathrm{dl}$; (Ht) hematocrit $23.00 \div 41.00 \%$; (RBC) red blood cell count $0.72 \div 2.10 \times 10^{6} / \mu \mathrm{l}$, (MCV) mean corpuscular volume $127 \div 346.37 \mu \mathrm{m} 3$, (MCH) mean corpuscular hemoglobin $18.62 \div 59.66 \mathrm{pg}$ and (MCHC) mean corpuscular hemoglobin concentration $12.65 \div 30.69 \mathrm{~g} / \mathrm{dl}$.

In the present research, these variations in the blood parameters underlined the role of the hematology in assessing the homeostatic response of fish to different technological conditions.
\end{abstract}

Keywords: carp, hematological parameters, probiotics, RAS

\section{INTRODUCTION}

The use of probiotics in aquaculture is gained increasing scientific and commercial interest for promoting as growth supplements, mostly, but as prophylactic or therapeutic agents, too. The intensive fish rearing often are characterized by stressful conditions (overcrowd, altered water quality etc.) so, the probiotics could help by enhancing the resistance to stress. In teleostean fish, hematological indices are used as indicators of the physiological stress response to internal or external factors disturbances. Currently, there 
is limited information on the efficacy of the probiotics and its impact on fish blood physiology.

The main variation of technological factors and also the management practices for recirculating aquaculture industrial systems, which involves high stocking densities, biological material handling, medication treatments, temperature variation and poor technological water quality, strongly affects fish growth in intensive conditions (Cristea et al., 2002).

Numerous studies have highlighted the special role of ensuring and maintaining quality feed in a normal physiological state. Both quantity and proportion of nutrients in fish feed can influence susceptibility to disease. Fish nutrition research has emphasized the importance of nutrients in maintaining normal immune function and resistance to disease (Docan et al., 2011).

It was reported that the hematological and biochemical parameters of fish could be used to evaluate the health condition of the organism. The microorganisms used as probiotics, including Lactobacillus, Bacillius and yeasts, have been reported in penaeids and fish (Capkin et al., 2009; Pooramini et al., 2009). Probiotics play important roles as immunostimulants and antimicrobial agents. Probiotics are live microbial or cultured product feed supplements that beneficially affect the host by producing inhibitory compounds, competing for chemical and adhesion sites, modulating and stimulating immune function, and improving microbial balance (Schaperclaus et al., 1992). In aquaculture, probiotics are used to control diseases, enhance specific and non-specific immunity, provide nutrients and enzymatic functions and improve water quality (Balcázar et al., 2006).

The general aim of this paper was to assess the effect of a probiotic supplements (BioPlus ${ }^{\circledR} 2 B$ ) on hematological status in common carp (Cyprinus carpio, Linnaeus 1758), cultured in a recirculating aquaculture system and fed with a commercial diet with $30 \%$ raw protein.

\section{MATERIALS AND METHODS}

The facilities used for this research was represented by the pilot recirculating system of the Aquaculture, Environmental Sciences and Cadastre Department, "Dunărea de Jos" University of Galati. The pilot recirculating grow system used for these experiments has been described, constructively speaking, also in other studies (Cristea et al., 2011) reason for which this paper no longer contains its description. The production system mainly consists in 4 rearing units, with a volume of $1 \mathrm{~m}^{3}$ each and also water quality conditioning units.

The experiment was conducted over a period of 60 days, between December 2010 and January 2011. The biological material used for this experiment was represented by carp juvenile, fish biomass being equally distributed into the four rearing units (V1-control and three different concentrations of probiotics: V2-2.24 $\times 10^{9} \mathrm{CFU} /$

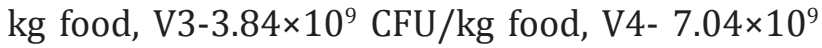
$\mathrm{CFU} / \mathrm{kg}$ food).

The hematological indices, such as the red blood cells number (RBCx $10^{6}$ cells/ $\mu$ l blood), hemoglobin ( $\mathrm{Hb}-\mathrm{g} / \mathrm{dl})$, hematocrit (Ht-\%) and the erythrocyte constants -the mean corpuscular volume (MCV$\mu \mathrm{m}^{3}$ ), the mean corpuscular hemoglobin (MCH-pg), the mean corpuscular hemoglobin concentration (MCHC-g/dl)- are important parameters for the evaluation of general physiological condition of the fish and their changes may be a response to various environmental conditions.

Erythrocytes (RBC) were counted immediately after blood collection in hemocytometer (Improved Neubauer Weber scientific Ltd.), according to (Wintrobe, 1934). For measuring hematocrit (Ht), heparinized hematocrit capillary tube were filled with blood and centrifuged for 5 minutes at 12000 rpm in a micro hematocrit centrifuge (Haematokrit 24. Hettich).

Hemoglobin (Hb) concentration was estimated as cyanmethemoglobin by adding $20 \mu \mathrm{l}$ of whole blood to $5 \mathrm{ml}$ of Drabkins solution and by using spectrophotometer (Specord 210-Analytic Jena), at a wavelength of $546 \mathrm{~nm}$, for determining the final values.

Using standard formulas, the red blood indices were computed: the mean corpuscular volume (MCV), the mean corpuscular hemoglobin $(\mathrm{MCH})$ and the mean corpuscular hemoglobin concentration (MCHC) (Dacie and Lewis, 2001).

Blood sampling for the hematological parameters determinations was performed both at initial stocking and at harvesting stages. A total of 40 fish were examined, five from each variant, respectively 20 fish from each of the two analyzed key moments. 
Carp specimens from which biological blood samples were collected had been marked with chip at the beginning of the experiment period, fact that provides a specific code for each of the analyzed fish. This procedure was applied in order to obtain a series of clear results regarding the hematological parameters analysis, performed during the experimental period.

The data were statistically analyzed in Microsoft Excel, using descriptive statistics and ANOVA and T-test.

\section{RESULTS AND DISCUSSION}

Research in this paper focused on the hematological response of juvenile carp (Cyprinus carpio, L. 1758) in condition of dietary supplementation with a commercial probiotic BioPlus ${ }^{\circledR} 2 B$ in three different concentrations.

Environmental or physiological stress causes rapid increase of blood hemoglobin concentration due to both recruitment of erythrocytes from spleen and hemoconcentration installation, as a consequence of plasma water loss (Nicula, 2004). Previous studies on fish hematology revealed that blood parameters levels could be affected by water temperature and oxygen concentration variations (Jewet et al., 1991).

The hematological modifications of our studied fish were analyzed in corroboration with the technological factors (water quality), which can influence the metabolic processes. In the present research, temperature was kept at a constant value during the whole experiment, the range value being between 13.5 and $16.8^{\circ} \mathrm{C}$, while the value of dissolved oxygen (DO) were in the range $4.2-8.1 \mathrm{mg} / \mathrm{l}$.

In Table 1, 3, 4 and 5 are shown the hematological parameters analyzed from fish blood samples and in Table 2 are presented the normal values for the main hematological parameters in C. carpio.

At the beginning of the experiment, hematological indices of $C$. carpio did not differ significantly between the experimental variants $(\mathrm{p}<0.05)$.

The lower values registered for $\mathrm{Hb}$ and $\mathrm{Ht}$, outside the normal range, are signs of anemia. Values that represent the number of red blood cells were within the normal range for carp blood parameters (Tab. 2).

This condition status weakens the body immune system, making fish susceptible to certain pathogens, while a decrease in tolerance to oxygen deficiency also reveals.

As it can be observed, at the beginning of the experimental period, the hemoglobin $(\mathrm{Hb})$ varied from $4.06 \mathrm{~g} / \mathrm{dl}$ in V4 case to $4.96 \mathrm{~g} /$ dl for control variant (V1). After 60 days of probiotic administration, significant changes are distinguished between V1 variant (control) and V2 $(\mathrm{p}<0.05 ; \mathrm{p}=0.02)$ and no significant changes between $\mathrm{V} 1$ and the other two experimental variants $(\mathrm{p}<0.05 ; \mathrm{p}=0.71 ; \mathrm{p}=0.41)$. Comparing the

Tab. 1. Variation of the hematological indices in C. carpio at the beginning experimental period.

\begin{tabular}{lcccccc}
\hline \multirow{2}{*}{$\begin{array}{l}\text { Experimental } \\
\text { variants }\end{array}$} & \multicolumn{2}{c}{$\mathrm{Hb}(\mathrm{g} / \mathrm{dl})$} & \multicolumn{2}{c}{$\mathrm{Ht}(\%)$} & \multicolumn{2}{c}{ Red blood cells $\left(10^{6} / \mu \mathrm{l}\right)$} \\
\cline { 2 - 7 } & min-max & Mean \pm SD & min-max & Mean \pm SD & min-max & Mean \pm SD \\
\hline V1 & $4.20-6.40$ & $4.96 \pm 0.79$ & $27-28$ & $27.4 \pm 0.49$ & $1.02-1.45$ & $1.27 \pm 0.18$ \\
\hline V2 & $3.90-6.70$ & $4.66 \pm 1.03$ & $24-36$ & $30 \pm 4.38$ & $1.22-1.40$ & $1.31 \pm 0.06$ \\
\hline V3 & $3.90-4.70$ & $4.22 \pm 0.28$ & $23-30$ & $25.8 \pm 2.48$ & $0.72-1.40$ & $1.02 \pm 0.22$ \\
\hline V4 & $3.40-5.90$ & $4.06 \pm 0.94$ & $24-29$ & $26.2 \pm 1.94$ & $0.91-1.88$ & $1.41 \pm 0.37$ \\
\hline
\end{tabular}

Tab. 2. Normal values for the main hematological parameters in Cyprinus carpio (Ghittino, 1983).

\begin{tabular}{lcccccc}
\hline Studied species & $\begin{array}{c}\text { Red blood cells } \\
\left(10^{6} / \mu \mathrm{l}\right)\end{array}$ & $\begin{array}{c}\mathrm{Hb} \\
(\mathrm{g} / \mathrm{dl})\end{array}$ & $\begin{array}{c}\mathrm{Ht} \\
(\%)\end{array}$ & $\begin{array}{c}\mathrm{MCV} \\
(\mu \mathrm{m} 3)\end{array}$ & $\begin{array}{c}\text { MHC } \\
(\mathrm{pg})\end{array}$ & $\begin{array}{c}\text { MCHC } \\
(\mathrm{g} / \mathrm{dl})\end{array}$ \\
\cline { 2 - 7 } Cyprinus carpio & $1.10-2.20$ & $6.5-10.6$ & $32-43.8$ & $152-364$ & $50-63$ & $15-25$ \\
\hline
\end{tabular}


Tab. 3. Variation of the erythrocyte constants of $C$. carpio at the beginning experimental period.

\begin{tabular}{|c|c|c|c|c|c|c|}
\hline \multirow{2}{*}{$\begin{array}{l}\text { Experimental } \\
\text { variants }\end{array}$} & \multicolumn{2}{|c|}{$\mathrm{MCV}$} & \multicolumn{2}{|c|}{$\mathrm{MCH}$} & \multicolumn{2}{|c|}{ MCHC } \\
\hline & $\min -\max$ & Mean \pm SD & $\min -\max$ & Mean \pm SD & $\min -\max$ & Mean \pm SD \\
\hline V1 & $\begin{array}{c}186.21- \\
266.01 \\
\end{array}$ & $219.98 \pm 31.07$ & $\begin{array}{c}30.93- \\
46.79 \\
\end{array}$ & $39.52 \pm 6.41$ & $\begin{array}{l}15.36- \\
22.86 \\
\end{array}$ & $18.09 \pm 2.73$ \\
\hline V2 & $\begin{array}{l}182.51- \\
278.69\end{array}$ & $229.17 \pm 34.33$ & $\begin{array}{c}29.66- \\
47.86\end{array}$ & $35.38 \pm 6.49$ & $\begin{array}{l}12.65- \\
18.61\end{array}$ & $15.50 \pm 1.94$ \\
\hline V3 & $\begin{array}{l}164.28- \\
333.33 \\
\end{array}$ & $263.16 \pm 56.24$ & $\begin{array}{c}27.86- \\
65.28 \\
\end{array}$ & $43.61 \pm 12.17$ & $\begin{array}{c}14- \\
19.58 \\
\end{array}$ & $16.49 \pm 1.82$ \\
\hline V4 & $\begin{array}{l}127.66- \\
298.34 \\
\end{array}$ & $199.62 \pm 58.84$ & $\begin{array}{l}18.62- \\
38.67\end{array}$ & $30.18 \pm 7.88$ & $\begin{array}{l}12.96- \\
20.34\end{array}$ & $15.37 \pm 2.56$ \\
\hline
\end{tabular}

Tab. 4. Variation of the hematological indices in C. carpio after feeding supplement probiotics.

\begin{tabular}{lcccccc}
\hline \multirow{2}{*}{$\begin{array}{l}\text { Experimental } \\
\text { variants }\end{array}$} & \multicolumn{2}{c}{$\mathrm{Hb}(\mathrm{g} / \mathrm{dl})$} & \multicolumn{2}{c}{$\mathrm{Ht}(\%)$} & \multicolumn{2}{c}{$\begin{array}{c}\text { Red blood } \\
\text { cells }\left(10^{6} / \mu \mathrm{l}\right)\end{array}$} \\
\cline { 2 - 7 } & min-max & Mean $\pm \mathrm{SD}$ & min-max & Mean $\pm \mathrm{SD}$ & $\min -\max$ & Mean $\pm \mathrm{SD}$ \\
\hline V1 & $6.90-8.80$ & $7.92 \pm 0.82$ & $26-36$ & $31.2 \pm 3.31$ & $0.89-1.52$ & $1.37 \pm 0.24$ \\
\hline V2 & $6.40-11$ & $7.92 \pm 1.62$ & $30-39$ & $33.20 \pm 3.31$ & $1.70-2.10$ & $1.93 \pm 0.13$ \\
\hline V3 & $6.00-8.90$ & $7.24 \pm 1.00$ & $29-41$ & $33 \pm 4.56$ & $1.14-1.84$ & $1.46 \pm 0.27$ \\
\hline V4 & $5.80-7.00$ & $6.30 \pm 0.46$ & $30-36$ & $32.8 \pm 2.32$ & $1.30-1.73$ & $1.58 \pm 0.16$ \\
\hline
\end{tabular}

Tab. 5. Variation of the erythrocyte constants of $C$. carpio after feeding supplement probiotics.

\begin{tabular}{|c|c|c|c|c|c|c|}
\hline \multirow{2}{*}{$\begin{array}{l}\text { Experimental } \\
\text { variants }\end{array}$} & \multicolumn{2}{|c|}{$\mathrm{MCV}$} & \multicolumn{2}{|c|}{$\mathrm{MCH}$} & \multicolumn{2}{|c|}{$\mathrm{MCHC}$} \\
\hline & $\min -\max$ & Mean \pm SD & $\min -\max$ & Mean \pm SD & min-max & Mean \pm SD \\
\hline V1 & $\begin{array}{l}172.18- \\
346.37\end{array}$ & $236.65 \pm 59.66$ & $\begin{array}{c}45.69- \\
97.21\end{array}$ & $60.80 \pm 18.89$ & $\begin{array}{c}23.33- \\
28.06\end{array}$ & $25.44 \pm 1.66$ \\
\hline V2 & $\begin{array}{l}142.52- \\
199.41 \\
\end{array}$ & $173.37 \pm 22.38$ & $\begin{array}{c}33.25- \\
55.00\end{array}$ & $41.24 \pm 8.41$ & $\begin{array}{l}19.39- \\
28.20 \\
\end{array}$ & $23.69 \pm 2.80$ \\
\hline V3 & $\begin{array}{l}190.22- \\
254.38\end{array}$ & $230.13 \pm 27.14$ & $\begin{array}{c}32.61- \\
77.39\end{array}$ & $52.60 \pm 16.45$ & $\begin{array}{l}17.14- \\
30.69\end{array}$ & $22.48 \pm 5.10$ \\
\hline V4 & $\begin{array}{l}182.93- \\
239.38\end{array}$ & $208.68 \pm 21.98$ & $\begin{array}{c}34.78- \\
44.79\end{array}$ & $39.10 \pm 3.28$ & $\begin{array}{l}17.14- \\
22.33\end{array}$ & $19.28 \pm 1.70$ \\
\hline
\end{tabular}

results for hematological indices with the initial values significant changes are reported $(\mathrm{p}<0.05)$.

Hematocrit ( $\mathrm{Ht}$ ), slight lower at the beginning of the experiment period, registered a wide range between $25.8 \%$ (V3) and 30\% (V2). No significant changes are related at the end of the experimental period $(\mathrm{p}<0.05 ; \mathrm{p}=0.60)$, values being between
$31.2 \%$ for the control variant and $33.20 \%$ (variant V2).

The number of erythrocytes, as it can be seen by analyzing the above values, is within the normality range for the analyzed species (Tab. 2). There have been no significant changes of this parameter in all four experimental variations $(p<0.05 ; p=0.20)$, the lowest value being recorded 
in V1 (control) and the highest in V2. Also, no significant changes of erythrocytes number are registered when we compare the initial values and the four experimental variants $(\mathrm{p}<0.05)$

After determining the hematological indices, carp erythrocytes constants were calculated, those having a particularly important diagnostic value as they help to detect physiologically damages in the formation process of hemoglobin, provides information regarding the size, shape and hemoglobin charge of erythrocyte.

Due to the influence of main technological factors that have acted on the biological material in current experiment (low technological water temperature and different probiotic concentrations), erythrocyte constants values showed the following changes:

Due to the decrease of technological water temperatures under the optimal physiological level, mean corpuscular volume (MCV) ranged from $199.62 \pm 58.84 \mu \mathrm{m}^{3}$ at V4 variant and $263.16 \pm 56.24 \mu \mathrm{m}^{3}$ in case of V3 (at the beginning of the experiment). At the end of the trial no significant changes are registered between control group (V1) and the three experimental variants $(p<0.05 ; p=0.21)$. Comparing with the beginning of experimental period MCV registered a significant increase $(p<0.05 ; p=0.02)$ in V1 variant and no significant changes in V2, V3 and V4 variant.

At the end of the experiment, Mean corpuscular hemoglobin (MCH) showed a significant increase comparing with the initial moment of the experiment $(p<0.05)$. Thus, a minimum average value of $30.18 \pm 7.88 \mathrm{pg}$ was registered for V4 variant on the initial moment and a maximum average value of $60.80 \pm 18.89 \mathrm{pg}$ was found in case of V1, at end of the experimental period. No significant changes were observed between the control variant and those supplemented with probiotic $(\mathrm{p}<0.05 ; \mathrm{p}=0.06)$.

Mean corpuscular hemoglobin concentration (MCHC) was maintained within the normality range for current experimental species (Tab. 2), showing a significant increase $(\mathrm{p}<0.05 ; \mathrm{p}=0.00007)$, with values of $15.37 \pm 2.56 \mathrm{~g} / \mathrm{dl}$ in $\mathrm{V} 4$ variant (initial) and $25.44 \pm 1.66 \mathrm{~g} / \mathrm{dl}$ for $\mathrm{V} 1$ in the final stage of the experiment.

The present findings confirm those reported by (Crețu et al., 2011) who revealed that blood hematological parameters (hemoglobin, erythrocytes count) in fish fed diets containing
Bioplus ${ }^{\circledR} 2 B$ (commercial probiotic consists on Bacillius licheliformes and Bacillius subtilis) were significantly higher compared to the control group.

Both hematological indicators and erythrocyte constants had values above or below the normality range of C. carpio, Linnaeus 1758, fact explained by the stressful effect of water temperature that had registered a significant decrease, under the optimum limit, from the technologically point of view. This has resulted in homeostasis disturbance of carp body, growth in recirculating aquaculture system conditions under the influence of environmental factors, by applying different concentrations of probiotic on their (Bocioc, 2011).

\section{CONCLUSION}

In the present research, these variations in the blood parameters underlined the role of the hematology in assessing the homeostatic response of fish to different technological conditions. From the data analysis regarding the hematological indicators that indicate the occurred changes in the conditions of main technological factors influence on the physiological status assessment of carp reared in recirculating system, it appears that probiotics can be used for health improvement and remediation, thus improving the resistance to disease and also the growth performance of biological material.

Acknowledgments. The work of Elena Bocioc was supported by Project SOP HRD - PERFORM /159/1.5/S/138963. The work of Alina Antache has been funded by the Sectoral Operational Programme Human Resources Development 20072013 of the Ministry of European Funds through the Financial Agreement POSDRU/159/1.5/S/132397 - ExcelDOC.

\section{REFERENCES}

1. Balcázar JL, de Blas I, Ruiz-Zarzuela I, Cunningham D, Vendrel D, Múzquiz JL (2006). The role of probiotics in aquaculture. Vet Microbiol; 114: 173-186.

2. Bocioc $E$ (2011). Reserches on the use of probiotics in industrial aquaculture within recirculating systems, $\mathrm{PhD}$ Thesis, University “Dunărea de Jos” Galati, 2011.

3. Capkin E, Altinok I (2009). Effects of dietary probiotic supplementations on prevention/treatment of yersiniosis disease. J Appl Microbiol; 106: 1147-1153. 
4. Cristea V, C Ceapa, I Grecu (2002). Recirculating aquaculture systems engineering, Didactic and Pedagogic Publishing House, Bucharest.

5. Cristea V, Ion (Placinta) S, Bocioc E, Ionescu TI, Coada MT and Enache I (2011). Monitoring the Water Quality in the Aquaculture Recirculating Systems, Journal of Environmental Protection and Ecology (JEPE), 12(4).

6. Dacie JV and Lewis SM (2001). Practical Haematology, $9^{\text {th }}$ edition. Churchill Livingstone, London, 633.

7. Docan A, Dediu L, Cristea V (2011). Effect of feeding with different dietary protein level on hematological indices of juvenile Siberian sturgeon, Acipenser baeri reared under recirculating systems condition. AACL Bioflux 4(2): 180186.

8. Ghittino P (1983). Techology and Pathology in Aquaculture. Vol 1, Bono, Torino.

9. Jewet MG, Behmen DJ and Johnson GH (1991). Effects of hyperoxic rearing water on blood haemoglobin and haematocrit level of Rainbow trout, J. Aquactic Anim. Health, 3, 153-160.
10. Pooramini M, Kamali A, Hajimoradloo A, Alizadeh M, Ghorbani R (2009). Effect of using yeast (Saccharomyces cerevisiae) as probiotic on growth parameters, survival and carcass quality in rainbow trout Oncorhynchus mykiss fry. Int Aquat Res; 1: 39-44.

11. Mocanu (Crețu) Mirela, Cristea Lorena Dediu, Elena Bocioc, Rodica Iulia Grecu, Săndița (Ion) Plăcintă, I Vasilean (2011). The effect of probiotic diet on growth and hematology parameters of rainbow trout (Oncorhynchus mykiss, W., 1792), University of Agricultural Sciences and Veterinary Medicine Iasi, 258-263.

12. Nicula M (2004). Fiziologia organismelor acvatice. I. Fiziologia peştilor. Vol. I. Ed. Mirton, Timişoara, 215.

13. Schaperclaus W, Kulow H, Schreckenbach K (1992). Fish diseases. $5^{\text {th }}$ ed. Rotterdam: A.A. Balkema; 594.

14. Wintrobe MM (1934). Variations of the size and haemoglobin content of erythrocytes in the blood various vertebrate, Folia Hematol., Leipzig; 51, 32-49. 